\title{
An Investigation of Secondary Students' Mental Models of Climate Change and Greenhouse Effect
}

\begin{abstract}
There are several studies dealing with students' conceptions on climate change, but most of them refer to understanding before instruction. In contrast, this study investigates students' conceptions and describes the levels of sophistication of their mental models on climate change and the greenhouse effect. The participants were 40 students of secondary education (Grade 7) in Spain. As a method of data collection, a questionnaire with open-ended questions focused on the mechanism, causes and actions that could be useful in reducing climate change was designed. Seventh grade students completed the same questionnaire before and after instruction. The students' conceptions and mental models were identified by an inductive and iterative analysis of the participants' explanations. With regard to the students' conceptions, the results show that they usually link climate change to an increase in temperature, and they tend to mention, even after instruction, generic actions to mitigate climate change, such as not polluting. With regard to the students' mental model, the results show an evolution of models with little consistency and coherence, such as the models on Level 1, towards higher levels of sophistication. The paper concludes with the educational implications proposed for solving learning difficulties regarding the greenhouse effect and climate change.
\end{abstract}

Keywords Alternative conceptions; Mental models; Climate change; Greenhouse effect. 


\section{Introduction}

Today, climate change is one of the world's most important problems of which virtually all the population is aware thanks to its presence in the scientific, social, political and economic debate in every country. As suggested by Arto and Meira (2011), we should be aware that society's knowledge, opinions and assessments of climate change feed on information from various media sources and the information may or may not originate from the field of science. Therefore, for teaching strategies used in the classroom to meet the objective of developing in individuals the ability to take mitigation and adaptation actions for climate change, we must remember that students already have their own ideas, valuations and representations of climate change.

In the field of science education numerous widely documented studies have been conducted on students' alternative ideas (e.g. Duit 2009). The studies began in the 1970s with the investigation of students' pre-instructional conceptions on various contents of science and, in these four decades, it has been one of the most important domains in educational research in this field. Since alternative conceptions are characterized by resistance to change, several researchers in the field of science education concluded that sometimes these ideas don't exist into the individuals' minds as isolated ideas, but they constitute a structured and coherent set of interconnected ideas (Chi 2008; Author 2012; Gutiérrez 2004). Thus, alternative conceptions can be structured in alternative explanatory models or mental models (Gilbert and Boulter 2000) that are consistent for the individuals who uphold them, even though in many cases these personal representations are incompatible with or contradict scientific model (Reinfried and Tempelmann 2014). While alternative conceptions are conceived as isolated ideas, mental models are constituted by a structure of beliefs and images that is generative, allowing individuals to explain and predict natural phenomena (Greca and Moreira 2000; Schwarz et al. 2009). However, it is important to note that if students construct mental models that involve many distortions, preconceptions and alternative ideas, they might lead to inaccurate explanations (Reinfried and Tempelmann 2014; Schraw et al. 2006).

Mental models, despite being structural analogues of the world, are incomplete due to the limited ability of students to represent the world (Jones et al. 2011). Mental models are also dynamic, since they are constantly subjected to a review process by students as they interact with facts and phenomena and are exposed to new knowledge, ideas and experiences, and they are non-scientific (Greca and Moreira 2000). 
Scientific or conceptual models are representations of phenomena, events or systems that are consistent with the knowledge accepted by the scientific community. Unlike mental models, conceptual models are characterized by elaborated images that explain the phenomena in specific detail, and are limited by scientific principles (Mohan et al. 2009). When students construct mental models that differ from the conceptual models that have been presented to them during schooling, a restructuration of existing cognitive structures must occur (Greca and Moreira 2000; Shepardson et al. 2017). In such cases, we face with the dilemma of how to change students' models (Schraw et al. 2006). Much has been written on conceptual change since it was first mentioned in the work of Posner et al. (1982). In the beginning, conceptual change just referred to alternative ideas, being considered as a restructuring or replacement of these ideas when students felt dissatisfied with them and perceived the new conception scientifically accepted as intelligible and plausible. When the construct of mental model began to be relevant in the field of science education, there was a change of perspective in the definition of conceptual change. Gadgil et al. (2012) view conceptual change as the transformation of prior knowledge that conflicts with new information. This transformation involves cognitive processes related to inference generation and mental models' revision with the goal of remove internal contradictions. The model's revision affects both the individual features of the model and the interrelationships between those features. Schraw et al. (2006) point out that conceptual change doesn't occur without some degree of intellectual conflict, although there is no an agreement on how much conflict is needed. In contrast, learning processes such as the addition of new knowledge when students lack prior knowledge or when they have some knowledge but incomplete are known as enrichment, and they do not constitute conceptual change (Chi 2008). By establishing an analogy between the terms used in the pioneering work of Posner et al. (1982), the enrichment is comparable to the process of assimilation, whereas during a radical change the process of accommodation prevails (Oliva, 1999).

Although the subject of climate change is one of the most important social scientific issues, numerous studies have shown that students' ideas and models about climate change are still inappropriate. Students must construct appropriate mental models to be able to integrate the functional and causal relationships of complex system like global climate (Schraw et al. 2006). Since complex systems consist of several components that interact among them in different ways, incorporating system thinking into the teaching of climate and climate change would result in a better understanding of its causes, changes and consequences (Author 1996; Roychoudhury et al. 2017). Further research is therefore necessary to gain a better understanding of students' ideas and models on climate change to plan the curriculum and design teaching materials in a way that challenge 
students' mental models allowing them to evolve towards those of school science (Schraw et al. 2006; Shepardson et al. 2011a). According to Anyanwu et al. (2015), individuals with higher levels of literacy in relation to climate change are more aware of the relationship between climate and human lifestyle and how the latter affects climate change. The relevance of this study is that it discusses alternative ideas and describes the levels of sophistication of students' models on climate change before and after instruction.

Therefore, the objectives of this study can be represented in the following research questions:

- What are students' alternative ideas on climate change and the greenhouse effect?

- At what levels of sophistication are their mental models on climate change and the greenhouse effect located?

- What are the differences between the students' mental models on climate change before and after instruction?

\section{Climate Change and Environmental Literacy}

In the United Nations Framework Convention on Climate Change (United Nations 1992), climate change is defined as "a change of climate which is attributed directly or indirectly to human activity that alters the composition of the global atmosphere and which is in addition to natural climate variability observed over comparable time periods" (p. 3).

According to the Intergovernmental Panel on Climate Change (IPCC 2014), global warming is unequivocal and a series of unprecedented changes have been observed since the 1950s. Man's action is clear and unquestionable in the rapid increase in climate change that has occurred in recent decades. Some of the changes that have taken place in the climate system are the warming of the atmosphere and oceans, declining volumes of ice and snow and rising sea levels. There have also been numerous impacts on natural and human systems, as well as episodes of extreme weather events (IPCC 2014).

One of the main causes of this global environmental problem is the enhanced greenhouse effect due to the emission of anthropogenic greenhouse gases (GHG), which have increased notably since pre-industrial times due to economic and population growth and today the levels are higher than ever (IPCC 2014). The greenhouse effect is a natural phenomenon which keeps the Earth warm enough to develop and sustain life. This occurs because some of the infrared radiation emitted from Earth towards space is absorbed and re-radiated in all directions by greenhouse gases in the atmosphere such as carbon dioxide $\left(\mathrm{CO}_{2}\right)$, methane $\left(\mathrm{CH}_{4}\right)$ or nitrous oxide 
$\left(\mathrm{N}_{2} \mathrm{O}\right)$. The enhanced greenhouse effect is the additional heat trapped due to the increase in greenhouse gases as a result of human activities. As IPCC (2014) stated, "since 1970, cumulative $\mathrm{CO}_{2}$ emissions from fossil fuels combustion, cement production and flaring have tripled, and cumulative $\mathrm{CO}_{2}$ emissions from forestry and other land use have increased by about 40\%" (p. 45). Concentrations of other anthropogenic greenhouse gases such as methane or nitrous oxide have also increased since 1750 by $150 \%$ and $20 \%$, respectively (IPCC 2014).

This paper is based on the consideration that one of the most urgent tasks of science education is to promote environmental literacy that allows students to understand how nature functions, why we generate negative impact with our activities, and how we can live in a more environmentally friendly way (see, e.g. Berkowitz et al. 2005). UNESCO (1989) defines environmental literacy as "a basic, functional education for all people, which provides them with the elementary knowledge, skills and motives to cope with environmental needs and contribute to sustainable development" (p. 1). Roth (1992) argues that environmental literacy involves more than cognitive skills, defining it as "the capacity to perceive and interpret the relative health of environmental systems and take appropriate action to maintain, restore, or improve the health of those systems" (p. 10). In this way, environmental literacy includes several components that can be grouped into cognitive, affective and behavioral, referring the cognitive domain to the knowledge of ecological processes that is needed for understanding human impact and natural systems (Roth 1992). This view is shared by Mohan et al. (2009) who also consider that one of the components of environmental literacy is specific knowledge which means, for example, that people must be able to interpret the transformations of matter that occurs in the carbon cycling to make responsible environmental decisions.

According to Roth (1992), environmental education is the means for developing environmental literacy. Other authors introduce the concept of sustainability arguing that environmental education is the means to achieve sustainable development by creating environmentally literate citizens who are willing to make informed decisions and act in the short and long term to maintain and enhance the environment (Goldman et al. 2014; Jickling and Wals 2008). Sustainable development refers to patterns of development that maintain a balance between the demand and consumption of natural resources, so that human needs are covered without irreversibly altering the physical environment (Bybee 1993). For science educators to appropriately address environmental issues, they should not focus on singular problems, but they should stablish a global perspective and develop the concepts, values and practices related to sustainable growth (Bybee 1993). A systemic learning 
approach that contributes to an understanding of the interrelationships between social and ecological systems is crucial for achieving sustainable development (Bybee 1993; Dyball et al. 2007).

Andersson and Wallin (2000) argue that environmental education is essential for people to be aware of the influence of sociocultural factors on the generation of environmental problems. These authors add that ignorance of the effects of a particular environmental problem in various fields (social, cultural, political, economic or institutional) generates answers not based on evidence and of limited feasibility (Andersson and Wallin, 2000). Apart from the need to confront different disciplines, the management of environmental problems involves a process of social learning and requires cooperation at different levels, including individual, community and government (Dyball et al. 2007). Other authors highlight the importance of understanding the biogeochemical processes that transform carbon compounds in natural systems to understand climate change (Mohan et al. 2009). These authors insist that the main cause of climate change is the worldwide unbalance among the processes that generate organic carbon through photosynthesis and those that transform and oxidize organic carbon. In this way, Miller and Anderson (2017) suggest teaching climate change from a carbon cycling perspective. This approach is based on the consideration that tracing matter and energy are fundamental practices for students to understand how anthropic activities lead to an increase in the level of atmospheric carbon dioxide, and how this increase causes the enhancement greenhouse effect.

Another problem revealed in numerous studies is the weak relationship between knowledge on climate change and pro-environmental attitudes (Karpudewan et al. 2015). This may be due to global environmental problems resulting from climate change not being perceivable by students' direct experience (Francis et al. 1993).

\section{Previous Studies on Alternative Ideas and Mental Models on Climate Change}

The first studies on students' conceptions of the greenhouse effect and climate change date back to the 90 s. Table 1 shows some results of the studies published form 2010 to present day we consider relevant to this investigation.

With the purpose of reporting a general summary which shows the diversity of students' conceptions about the greenhouse effect and global warming, we focus the description of previous findings in four fundamental aspects: 1) what greenhouse effect and climate change is, 2) the causes of climate change, 3) impact of climate change on humans and the natural environment, and 4) actions to slow down climate change. 
This is a post-peer-review, pre-copyedit version of an article published inResearch in Science Education. The final authenticated version is available online at: https://doi.org/10.1007/s11165-018-9703-1

Regarding the first aspect, research has revealed that, in general, students do not know what the greenhouse effect is, do not distinguish between global warming and the greenhouse effect and/or link these atmospheric phenomena with the destruction of the ozone layer (Andersson and Wallin 2000; Boyes and Stanisstreet 1993; Fisher 1998; Authors 2012; Groves and Pugh 1999; Klosterman and Sadler 2010; Liarakou et al. 2011; Meadows and Wiesenmayer 1999; Pruneau et al. 2001; Punter et al. 2011; Yazdanparast et al. 2013). Moreover, in some cases, this confusion of ideas between the greenhouse effect and the ozone layer is maintained despite instruction (see, e.g., Fisher 1998; Authors 2012). Furthermore, the lack of knowledge about what the greenhouse effect and climate change are concerns not only mid-level students. Fernández et al. (2011) noted that the knowledge possessed by university students on climate change does not differ significantly from that of most of the population, perceiving in their discourse an influence of the media, which was not expected, especially among students of science-related degrees, which should be able to clarify certain aspects such as the fact that climate change is a broader term that includes other environmental problems besides global warming.

Table 1 Previous research on the understanding of students and pre-service teachers on climate change

\begin{tabular}{|c|c|c|c|}
\hline Authors/Year & Participants/Ages & Method & Results \\
\hline $\begin{array}{l}\text { Klosterman } \\
\text { and Sadler } \\
2010\end{array}$ & $\begin{array}{l}108 \text { students } \\
15-16 \text { years }\end{array}$ & $\begin{array}{l}\text { Questionnaire with } \\
\text { open-ended and } \\
\text { closed questions. }\end{array}$ & $\begin{array}{l}\text { After examining social scientific issues, students } \\
\text { reached more precise levels of knowledge, although } \\
\text { they maintained certain alternative conceptions such } \\
\text { as relating the destruction of the ozone layer to } \\
\text { global warming. }\end{array}$ \\
\hline $\begin{array}{l}\text { Aydin and } \\
\text { Coşkun } \\
2010\end{array}$ & $\begin{array}{l}553 \text { students } \\
12-13 \text { years }\end{array}$ & $\begin{array}{l}\text { Interviews and } \\
\text { questionnaire with } \\
\text { open-ended } \\
\text { questions. }\end{array}$ & $\begin{array}{l}\text { The most recurring idea among students was that } \\
\text { human actions are the main cause of global warming } \\
(18 \%) \text {. }\end{array}$ \\
\hline $\begin{array}{l}\text { Fernández et } \\
\text { al. } \\
2011\end{array}$ & $\begin{array}{l}506 \text { university } \\
\text { students }\end{array}$ & $\begin{array}{l}\text { Questionnaire } \\
\text { open-ended } \\
\text { closed tasks. }\end{array}$ & $\begin{array}{l}\text { Most of the students linked climate change to } \\
\text { increasing } \mathrm{CO}_{2} \text { concentrations in the atmosphere, } \\
\text { without referring to other long-term greenhouse } \\
\text { gases such as methane. }\end{array}$ \\
\hline $\begin{array}{l}\text { Liarakou et al. } \\
2011\end{array}$ & $\begin{array}{l}\text { ents } \\
\text { d } 16-17\end{array}$ & $\begin{array}{l}\text { Questionnaire with } \\
22 \\
\text { questions. }\end{array}$ & $\begin{array}{l}63.26 \% \text { of students claimed that the destruction of the } \\
\text { ozone layer increases the greenhouse effect. }\end{array}$ \\
\hline $\begin{array}{l}\text { Punter et al. } \\
2011\end{array}$ & $\begin{array}{l}379 \text { students } \\
12-16 \text { years }\end{array}$ & $\begin{array}{l}\text { Questionnaire with } \\
\text { open-ended and } \\
\text { closed questions. }\end{array}$ & $\begin{array}{l}\text { Participants showed a confusion of ideas between } \\
\text { climate change and ozone depletion. }\end{array}$ \\
\hline $\begin{array}{l}\text { Shepardson et } \\
\text { al. } \\
\text { 2011a }\end{array}$ & $\begin{array}{l}225 \text { students } \\
12-13 \text { years }\end{array}$ & $\begin{array}{l}\text { Predict-Observe- } \\
\text { Explain (POE) } \\
\text { strategy }\end{array}$ & $\begin{array}{l}\text { Five mental models were identified, three of which } \\
\text { could easily be made to evolve towards the models } \\
\text { of school science through curricular content and } \\
\text { appropriate teaching activities. }\end{array}$ \\
\hline $\begin{array}{l}\text { Fernández et } \\
\text { al. } \\
2011\end{array}$ & $\begin{array}{l}506 \text { university } \\
\text { students }\end{array}$ & $\begin{array}{cc}\text { Questionnaire } & \text { with } \\
\text { open-ended } & \text { and } \\
\text { closed tasks. } & \end{array}$ & $\begin{array}{l}\text { Most of the students linked climate change to } \\
\text { increasing } \mathrm{CO}_{2} \text { concentrations in the atmosphere, } \\
\text { without referring to other long-term greenhouse } \\
\text { gases such as methane. }\end{array}$ \\
\hline $\begin{array}{l}\text { Liarakou et al. } \\
2011\end{array}$ & $\begin{array}{l}626 \text { students } \\
13-14 \text { and } 16-17 \\
\text { years }\end{array}$ & $\begin{array}{l}\text { Questionnaire with } \\
22 \quad \text { closed } \\
\text { questions. }\end{array}$ & $\begin{array}{l}63.26 \% \text { of students claimed that the destruction of the } \\
\text { ozone layer increases the greenhouse effect. }\end{array}$ \\
\hline Punter et al. & 379 students & Questionnaire & Participants sh \\
\hline
\end{tabular}


2011

Shepardson et

al.

$2011 \mathrm{a}$

Shepardson et

al.

$2011 b$

Chhokar et al. 2011
12-16 years

225 students

12-13 years

51 secondary school students

768 students

11-16 years open-ended and

closed questions.

Predict-Observe-

Explain

(POE)

strategy

Questionnaire with four open-ended questions and one drawing.

Questionnaire with 44 closed questions. climate change and ozone depletion.

Five mental models were identified, three of which could easily be made to evolve towards the models of school science through curricular content and appropriate teaching activities.

$45 \%$ of students did not think global warming could affect society because they trusted in the ability of human beings to develop technologies that would reduce climate change or enable us to adapt to the changes it causes.

It was found that Indian students show a stronger willingness to undertake actions pro-environmental than European or Australian students.

Table 1 Previous research on the understanding of students and pre-service teachers on climate change (continued)

\begin{tabular}{|c|c|c|}
\hline Authors/Year & Participants/Ages & Method \\
\hline Authors & 22 students & Questionnaire with \\
\hline 2012 & $15-16$ years & $\begin{array}{l}\text { open-ended anc } \\
\text { closed questions. }\end{array}$ \\
\hline $\begin{array}{l}\text { Ratinen et al. } \\
2013\end{array}$ & $\begin{array}{l}20 \text { pre-service } \\
\text { primary } \\
\text { teachers }\end{array}$ & $\begin{array}{l}\text { Essays writings, } \\
\text { drawings and } \\
\text { video recordings. }\end{array}$ \\
\hline $\begin{array}{l}\text { Yazdanparast } \\
\text { et al. } \\
2013\end{array}$ & $\begin{array}{l}1035 \text { secondary } \\
\text { school students. }\end{array}$ & $\begin{array}{l}\text { Questionnaire witl } \\
42 \text { open-endec } \\
\text { and closec } \\
\text { questions. }\end{array}$ \\
\hline $\begin{array}{l}\text { Karpudewan } \\
\text { et al. } \\
2014\end{array}$ & $\begin{array}{l}73 \text { students } \\
16-17 \text { years }\end{array}$ & $\begin{array}{l}\text { Questionnaire witl } \\
\text { open-ended anc } \\
\text { closed questions. }\end{array}$ \\
\hline $\begin{array}{l}\text { Bodzin et al. } \\
2014\end{array}$ & $\begin{array}{l}868 \text { students } \\
13-14\end{array}$ & $\begin{array}{l}\text { Questionnaire with } \\
\text { open-ended anc } \\
\text { multiple choice } \\
\text { questions. }\end{array}$ \\
\hline $\begin{array}{l}\text { Reinfried and } \\
\text { Tempelmann } \\
2014\end{array}$ & $\begin{array}{l}14 \text { students } \\
13 \text { years }\end{array}$ & $\begin{array}{l}\text { Drawings } \\
\text { interviews. }\end{array}$ \\
\hline $\begin{array}{l}\text { Kroufek } \\
2014\end{array}$ & $\begin{array}{l}15 \\
\text { Pre-service } \\
\text { teachers }\end{array}$ & Conceptual maps. \\
\hline $\begin{array}{l}\text { Anyanwu et } \\
\text { al. } \\
2015\end{array}$ & $\begin{array}{l}194 \text { secondary } \\
\text { teachers of } \\
\text { Geography }\end{array}$ & $\begin{array}{l}\text { Questionnaire with } \\
15 \text { multiple- } \\
\text { choice questions. }\end{array}$ \\
\hline $\begin{array}{l}\text { Karpudewan } \\
\text { et al. } \\
2015\end{array}$ & $\begin{array}{l}115 \text { students } \\
11 \text { years }\end{array}$ & $\begin{array}{l}\text { Questionnaire with } \\
\text { closed questions } \\
\text { and interviews. }\end{array}$ \\
\hline $\begin{array}{l}\text { Bofferding } \\
\text { and Kloser } \\
2015\end{array}$ & $\begin{array}{l}387 \text { students } \\
11-18 \text { years }\end{array}$ & $\begin{array}{l}\text { Questionnaire with } \\
\text { open-ended } \\
\text { questions. }\end{array}$ \\
\hline $\begin{array}{l}\text { Dawson } \\
2015\end{array}$ & $\begin{array}{l}438 \text { students } \\
14-15 \text { years }\end{array}$ & $\begin{array}{l}\text { Questionnaire with } \\
\text { open-ended } \\
\text { questions and } \\
\text { interviews. }\end{array}$ \\
\hline $\begin{array}{l}\text { Christensen } \\
\text { and Knezek }\end{array}$ & $\begin{array}{l}1576 \text { students } \\
10-14 \text { years }\end{array}$ & $\begin{array}{l}\text { Climate Change } \\
\text { Attitude Survey }\end{array}$ \\
\hline
\end{tabular}

$25 \%$ of students said that the destruction of the ozone layer intensifies the greenhouse effect.

Most of the participants, even after instruction, didn't relate an increase in levels of greenhouse gases to climate change.

$71.2 \%$ of participants thought that global warming increased the number of cases of skin cancer.

They found that a curriculum based on constructivist principles led to a reduction of alternative ideas on environmental issues such as global warming.

$69.6 \%$ of students did not realise that water vapour contributed to the greenhouse effect and only $22.4 \%$ of students associated tropospheric ozone with climate change.

Three mental models were identified: (1) isolated pieces of knowledge; (2) reduced heat input; and (3) increase in heat input.

The most common alternative conceptions were the destruction of the ozone layer as a prerequisite for the emergence of climate change and the link between this environmental problem and the release of water vapour from the melting icecaps.

Despite a high level of literacy in the causes and mechanism of climate change, they did not readily recognise water vapour as the main contributor to the natural greenhouse effect or understand the concept of carbon sink.

It was found that the 5E learning approach improves students' knowledge of climate change and causes a change in attitude towards more correct forms from an environmental perspective.

After instruction, only $10 \%$ of students proposed measures to reduce $\mathrm{CO}_{2}$ emissions to mitigate climate change.

$20 \%$ of students said that climate change was related to the greenhouse effect.

A relationship was found between students' beliefs about the climate and their ability to take action to mitigate climate 
2015

Chang and

Pascua

2016

Harris and

Gold

2017
(CCAS)

27 students

14-15 years

164 college students
Semi-structured interviews

Sketches of the greenhouse effect before and after a 30-min lesson change.

Some participants exhibited a hybrid model in which climate change is caused due to an interaction between the ozone layer and greenhouse gases.

They identified seven mental models on greenhouse effect and found that an approach based on learning about molecular-scale greenhouse gases behaviour allows an evolution of non-expertise models towards the scientific model.

Regarding the causes of climate change, in addition to the destruction of the ozone layer, Taber and Taylor (2008) found that 29 primary school students (12-13 years) considered, even after a teaching activity on climate change, that the use of nuclear energy contributed to global warming. Later, Punter et al. (2011) detected that students did not include energy consumed in homes or deforestation as causes of climate change, while they did associate this environmental problem directly with emissions from factories and motor vehicles. Another noteworthy finding in relation to the causes of climate change was that students identified carbon dioxide as a greenhouse gas, but not other gases such as methane, chlorofluorocarbons (CFCs), nitrous oxide or tropospheric ozone (Bodzin et al. 2014; Fernández et al. 2011; Fisher 1998). Kilinç et al. (2008) attributed the low proportion of students who identified tropospheric ozone as a greenhouse gas to students' difficulty in differentiating between stratospheric and tropospheric ozone, where this gas has always been considered beneficial thanks to the fact that it offers protection from ultraviolet radiation.

With regard to the consequences of climate change, several studies have showed that a significant proportion of students mistakenly believed that global warming could have a negative influence on the number of people diagnosed with skin cancer (Boyes and Stanisstreet 1993; Groves and Pugh 1999; Liarakou et al. 2011; Pruneau et al. 2003; Yazdanparast et al. 2013). There have also been studies in which it was found that certain students do not understand the immediate or future impact global warming may have on society (Pruneau et al. 2001; Shepardson et al. 2011b). Kilinç et al. (2008) found that fewer than half of the secondary school students (15-16 years) who participated in their study acknowledged that an increase in temperatures due to global warming could lead to an expansion of the geographical distribution of certain living beings, such as insects.

In general, students seem to have a better understanding of the actions that could be taken to slow down climate change than of its causes and consequences (Groves and Pugh 1999) and although they lack specific knowledge about the actions that could be undertaken to curb climate change, students also show great concern for the environment and are aware of their important role as citizens in combating environmental problems in 
This is a post-peer-review, pre-copyedit version of an article published inResearch in Science Education. The final authenticated version is available online at: https://doi.org/10.1007/s11165-018-9703-1

general and climate change in particular (Papadimitriou 2004). For example, Bodzin et al. (2014) noted that most of the students were able to cite several personal and social actions to reduce carbon dioxide emissions into the atmosphere, including changing transport habits, reducing electricity consumption, using renewable energy sources or planting trees.

Other authors went further in studying students' understanding of climate change, inferring the mental models in which students' ideas of climate change were structured (e. g. Andersson and Wallin 2000; Chang and Pascua 2016; Authors 2012; Harris and Gold 2017; Koulaidis and Christidou 1999; Reinfried and Tempelmann 2014; Shepardson et al. 2011a). Authors (2012) noted that the initial models with strong internal coherence for students were used as structures to accommodate new information, but the alternative models were not modified in any substantial way. Shepardson et al. (2011a) identified five mental models on climate change and found that three of them are likely to be easily modified through appropriate teaching activities and curriculum. These authors claimed that the most difficult models to modify are the most coherent. Such is the case of the model that considers that greenhouse gases cause ozone depletion or formation which allows more of the sun's rays to reach the Earth or causes the sun's rays to be trapped. Therefore, what inhibits the development of students' mental models is the existence of ideas that, although they may be alternatives, are interconnected in a way that provide a high coherence to the model. Instead, the descriptive models or those constituted by ideas close to the ideas that integrate the model of school science are easy to change. Other authors such as Reinfried and Tempelmann (2014) identified three alternative conceptions of the greenhouse effect, each describing a different initial mental model. These authors found that the learning pathway followed in the evolution of students' models to those of school science depends on their previous knowledge. These authors also claimed that representations with greater explanatory power are more difficult to change because students must transform their subjective coherent models to construct a totally different model. On the other hand, McGinnis et al. (2017) developed a learning progression for three consequences of climate change: enhanced urban heat island effect, extreme weather and sea level rise. These authors observed that when students describe the causes and mechanisms of sea level rise, they advance from macroscopic to microscopic explanations.

\section{Methodology}


This is a post-peer-review, pre-copyedit version of an article published inResearch in Science Education. The final authenticated version is available online at: https://doi.org/10.1007/s11165-018-9703-1

In this paper, a qualitative methodological approach is used and it constitutes a case study. This approach allows investigating a phenomenon in its real context (Yin 2003), deepening its knowledge through a study of a small group of students (Taylor and Bodgan 1998). It is clear that this type of study doesn't seek to generalise results and conclusions to other studies, but it does allow for comparisons with other studies of similar nature. The coincidence of results, or common patterns, is what allows a certain degree of generalization.

\section{Participants and Context}

This research was conducted at a secondary school in Santiago de Compostela, a city in north-western Spain. The participants were 40 seventh grade students (12-13 years) who received specific instruction about climate change. This topic was addressed in a teaching unit on the atmosphere. This unit lasted five 50-minute sessions and included the following contents: structure, composition and functions of the atmosphere; impact of human activities on the atmosphere; air pollution and associated environmental problems; the natural and the enhanced greenhouse effect. As showed in Table 2, the first activity of the unit was the pre-test. In the second activity, participants watched a 20-minute video, answered a series of questions individually and discussed about these questions in large group. The video content addressed the structure, the composition and the major environmental problems in the atmosphere, identifying causes, effects and possible solutions regarding climate change. After watching the video, the teacher projected different slides to explain what the atmosphere is and its different stages (troposphere, stratosphere, mesosphere, thermosphere, and exosphere). She also described the functions of the atmosphere, among them the regulation of the temperature, distinguishing between the natural greenhouse effect and the enhanced greenhouse effect, and explained the greenhouse gases. Besides these explanations, she showed students different diagrams of the mechanisms of the greenhouse effect, and addressed different actions to slow down climate change, among them planting trees. The third activity was a negotiation table in which students prepared a series of arguments for or against the construction of a thermal power plant in their city. For this they were provided with different materials with data from which they could prepare their arguments. It's important to note that the teaching unit was designed by the teacher, without the intervention of the researchers. It means that she did during the classes what she used to do, without any patterns established by the research.

On the other hand, the textbook used by the students in their daily classes included a teaching unit dedicated to the atmosphere and its major environmental problems. Although the purpose of this study is not to do a systematic analysis of textbooks to see how the topic of climate change is addressed, it is worth mentioning 
This is a post-peer-review, pre-copyedit version of an article published inResearch in Science Education. The final authenticated version is available online at: https://doi.org/10.1007/s11165-018-9703-1

for a further discussion of the results that the students' textbook included some elements that may lead to common misconceptions. For example, there were diagrams to explain the mechanism of the greenhouse effect that show the existence of a greenhouse layer above the Earth's that traps and reflects the sun's rays. These diagrams also included factories discharging air pollutants into the atmosphere as if pollution in general increases the greenhouse effect. In addition, the textbook presented the environmental problems in the atmosphere under the same title as if they were the same thing.

Table 2 Sequence of activities related to climate change implemented in the classroom

\begin{tabular}{llll}
\hline $\begin{array}{l}\text { No. of } \\
\text { activity }\end{array}$ & Activity & Objectives for students & Content \\
\hline 1 & $\begin{array}{c}\text { Pre-test }\left(1^{\text {st }} \text { session }\right) \\
\text { The atmosphere and } \\
\text { climate change }\left(2^{\text {nd }}\right. \\
\left.\text { and } 3^{\text {rd }} \text { sessions }\right)\end{array}$ & $\begin{array}{c}\text { Express and learn about their initial ideas. } \\
\text { Identify the major environmental problems } \\
\text { in the atmosphere and their causes. }\end{array}$ & $\begin{array}{c}- \\
\text { Structure, composition and major } \\
\text { environmental problems in the } \\
\text { atmosphere. }\end{array}$ \\
3 & $\begin{array}{c}\text { Negotiation table }\left(4^{\text {th }}\right. \\
\left.\text { and } 5^{\text {th }} \text { sessions }\right)\end{array}$ & $\begin{array}{c}\text { In practical way, relate human activities } \\
\text { to their impact on the atmosphere. } \\
\text { Propose agreed solutions. }\end{array}$ & $\begin{array}{c}\text { Impact of human activities on the } \\
\text { atmosphere. Greenhouse gases. }\end{array}$ \\
\hline
\end{tabular}

\section{Data Collection}

The participants responded individually to the same questionnaire before and after instruction. Thus, from this point on we will refer to the questionnaire as pre-test and post-test to differentiate the moment when it was completed. The questionnaire (Table 3) used as a data-collection instrument is inspired by previous papers (Boyes and Stanisstreet 1993; Dawson 2015; Dove 1996; Authors 2012; Karpudewan et al. 2015; Klosterman and Sadler 2010; Punter et al. 2011). Open-ended questions were preferred since they left room for a more accurate description of students' conceptions and mental models than closed questions.

Table 3 shows the items of the questionnaire. In order to justify why this instrument was created, we describe below the purpose of each question. The first question aims to make explicit the students' ideas about what is climate change. The second question was taken from the questionnaire of Dawson (2015) and aims to indicate what causes climate change. The third question was adapted from the questionnaire of Klosterman and Sadler (2010) and aims to know to what extent students distinguish between the greenhouse effect and climate change. The fourth question was taken from the questionnaire of Dove (1996) and its purpose is for students to represent their ideas about the greenhouse effect. The students' drawings might be considered representations of their mental models and show characteristics of these models that are inaccessible though other procedures (Shepardson et al. 2011a; White and Gunstone 1992). The purpose of the fifth question is for students to suggest actions to slow down climate change. 
This is a post-peer-review, pre-copyedit version of an article published inResearch in Science Education. The final authenticated version is available online at: https://doi.org/10.1007/s11165-018-9703-1

Table 3 Questionnaire items

1 What is climate change? Explain it in your own words.

2 What are the causes of climate change?

3 Are the greenhouse effect and climate change the same thing? Why?

4 Try to illustrate the greenhouse effect using this diagram.



\section{Data Analysis}

The students' answers were subjected to two types of analysis. The first analysis was aimed to identify the conceptions held by students, and the second one to identify their mental models before and after instruction. During the first analysis (reading and preliminary interpretation of the answers to each question), categories were generated describing the key ideas or elements of explanation to which students referred in their answers (Fisher 1998). In order to provide a degree of triangulation and increase the validity of the qualitative analysis, the process of generating categories was carried out by the researchers independently (Patton 2002). To ensure the coding was consistent, an inter-rater reliability coefficient was calculated by comparing the authors' coding. An $80 \%$ level of inter-rater reliability was achieved. The discrepant categories were reviewed several times by the researchers until a consensus was reached. In this inductive and iterative process, meanings were constructed from data (Patton 2002). When we refer to the data analysis as inductive, we want to express that categories were inferred in interaction with data. However, when the students' responses were similar to those described in previous studies on climate change, categories used in these studies were adapted.

This first analysis made it possible to describe the frequency of certain elements of explanation, both before and after instruction. In a second stage, each questionnaire was analysed globally, incorporating each student's conceptions in broader constructs, to which we refer as the students' explanatory models or mental models (Authors 2012; Reinfried and Tempelmann 2014; Shepardson et al. 2011a). The pre-test was used to infer an initial model and the post-test was used for a final model, which made it possible to examine the evolution of each student's model by comparing the two. In addition, as mental models are idiosyncratic in 
This is a post-peer-review, pre-copyedit version of an article published inResearch in Science Education. The final authenticated version is available online at: https://doi.org/10.1007/s11165-018-9703-1

nature, it was decided to go one step further in the analysis by setting different levels of sophistication in the inferred mental models so that each level groups together the models that have several characteristics in common.

\section{Findings and Discussion}

In order to clarify the presentation of data, this section is divided into two subsections. The first subsection includes a description of students' conceptions on climate change. For each question, we first present the results obtained in this study, together with the categories used for the analysis. Secondly, the findings that support or refute previous research on climate change are discussed. Regarding categories, each one is accompanied by a number representing the frequency with which each element of explanation appears in the participants' answers. It is important to note that, as they are open-ended questions, a student can refer to several elements of explanation in the same answer. For this reason, the sum of the frequencies of all the categories may be higher than the number of participants. Moreover, in some questions, each category is illustrated by the students' written work. In the second subsection, a description is given of the levels established for the mental models regarding the greenhouse effect and an analysis is made of their evolution in each participant after instruction. In any case, to protect the students' identities, they were assigned codes.

\section{Results and Discussion of the First Analysis: Conceptions on Climate Change}

Question 1: What Is Climate Change? The analysis of the students' answers to this question identified six main categories (Table 4). The answers considered correct or partially correct were grouped together in four of the categories and they were obtained by adapting some of the categories used by Klosterman and Sadler (2010) and Dawson (2015) in their studies. The other answers were grouped into the two remaining categories, classified as wrong answer or no answer.

From the results obtained in this study, it is noted that most answers corresponded to the category that mentions only the increase in temperature, both before (40\%) and after (43\%) instruction. Moreover, when comparing the pre-test and the post-test results, the proportion of students who included in their descriptions of climate change the increase in the temperature due to the influence of the enhanced greenhouse effect increased by $15 \%$. 
This is a post-peer-review, pre-copyedit version of an article published inResearch in Science Education. The final authenticated version is available online at: https://doi.org/10.1007/s11165-018-9703-1

Regarding previous research, it is observed that, in contrast to Dawson's study (2015) in which a small proportion of students gave responses noting that climate change was a change in weather patterns, students' answers in our study frequently linked climate change to a change in climate.

Table 4 Frequency and percentage of references to the different elements of explanation in the answers to the question: What is climate change? $(\mathrm{N}=40)$

\begin{tabular}{|c|c|c|c|}
\hline Categories & Examples & $\begin{array}{l}7^{\text {th }} \text { grade } \\
(12-13 \text { years }) \\
\text { Pre-test }\end{array}$ & $\begin{array}{l}7^{\text {th }} \text { grade } \\
(12-13 \text { years }) \\
\text { Post-test }\end{array}$ \\
\hline $\begin{array}{l}\text { Climate change is associated with a } \\
\text { change in climate and/or an increase } \\
\text { in temperature as a result of the } \\
\text { greenhouse effect or the } \\
\text { accumulation of greenhouse gases } \\
\text { (right answer). }\end{array}$ & $\begin{array}{l}\text { It is a consequence of the increase } \\
\text { in the greenhouse effect, in } \\
\text { which the temperature of the } \\
\text { Earth increases (post-test, } \\
\text { student 9). }\end{array}$ & $3(8 \%)$ & $9(23 \%)$ \\
\hline $\begin{array}{l}\text { Links climate change to an increase in } \\
\text { temperature with the associated } \\
\text { consequences (partially right } \\
\text { answer). }\end{array}$ & $\begin{array}{l}\text { It is the increase in global } \\
\text { temperature, causing damage } \\
\text { such as melting icecaps and } \\
\text { rising sea levels (pre-test, } \\
\text { student 26). }\end{array}$ & $3(8 \%)$ & $0(0 \%)$ \\
\hline $\begin{array}{l}\text { Links climate change to an increase in } \\
\text { temperature (partially right answer). }\end{array}$ & $\begin{array}{l}\text { It is the increase in temperature } \\
\text { (pre-test, student 23). }\end{array}$ & $16(40 \%)$ & $17(43 \%)$ \\
\hline $\begin{array}{l}\text { Links climate change to a change in } \\
\text { climate. }\end{array}$ & $\begin{array}{l}\text { When the climate changes (pre- } \\
\text { test, student } 4 \text { ). }\end{array}$ & $13(33 \%)$ & $10(25 \%)$ \\
\hline Wrong answer & $\begin{array}{l}\text { It is the reaction that occurs when } \\
\text { one of the factors and the } \\
\text { ecosystems are not regulated } \\
\text { (pre-test, student 19). }\end{array}$ & $4(10 \%)$ & $1(3 \%)$ \\
\hline No answer. & - & $1(3 \%)$ & $3(8 \%)$ \\
\hline
\end{tabular}

Question 2: What Are the Causes of Climate Change? The categorisation of the answers to this question is given in Table 5. Of the 16 categories defined in this study, some of them grouped together the wrong answers, showing the students' alternative ideas regarding the causes of climate change. The categories named as increase in the greenhouse effect, greenhouse effect, GHG emissions, $\mathrm{CO}_{2}$ emissions, CFC emissions, aerosols, pollution or pollutant gases, human activities, deforestation, acid rain and destruction of ozone layer were adapted in interaction with data from other studies (Authors 2012; Kilinç et al. 2008; Papadimitriou 2004; Punter et al. 2011).

As shown in Table 5, the results of this study indicate that the categories most often cited in the pre-test by $7^{\text {th }}$ grade students were referred to pollution $(50 \%)$ and carbon dioxide emissions (18\%). Pollution was interpreted as a generic answer because, although there are multiple pollutants, they do not all contribute to 
This is a post-peer-review, pre-copyedit version of an article published inResearch in Science Education. The final authenticated version is available online at: https://doi.org/10.1007/s11165-018-9703-1

climate change. It is also worth mentioning that some students showed confusion between causes and effects or consequences, since they referred to rising temperatures and the melting icecaps as causes of climate change.

Table 5 Frequency and percentage of references to different elements of explanation in the answers to the question: What are the causes of climate change? $(\mathrm{N}=40)$

\begin{tabular}{|c|c|c|c|}
\hline \multicolumn{2}{|l|}{ Categories } & $\begin{array}{l}7^{\text {th }} \text { grade } \\
\text { (12-13 years) } \\
\text { Pre-test }\end{array}$ & $\begin{array}{l}7^{\text {th }} \text { grade } \\
\text { (12-13 years) } \\
\text { Post-test }\end{array}$ \\
\hline \multicolumn{2}{|l|}{ Increase in the greenhouse effect. } & $0(0 \%)$ & $12(30 \%)$ \\
\hline \multicolumn{2}{|l|}{ Greenhouse effect. } & $2(5 \%)$ & $3(10 \%)$ \\
\hline \multicolumn{2}{|l|}{ GHG emissions. } & $3(8 \%)$ & $8(20 \%)$ \\
\hline \multicolumn{2}{|l|}{$\mathrm{CO}_{2}$ emissions. } & $7(18 \%)$ & $1(3 \%)$ \\
\hline \multicolumn{2}{|l|}{ CFC emissions. } & $0(0 \%)$ & $1(3 \%)$ \\
\hline \multicolumn{2}{|l|}{ Aerosols. } & $0(0 \%)$ & $1(3 \%)$ \\
\hline \multicolumn{2}{|l|}{ Pollution or pollutant gases. } & $20(50 \%)$ & $12(30 \%)$ \\
\hline \multicolumn{2}{|l|}{ Human activities. } & $5(13 \%)$ & $8(20 \%)$ \\
\hline \multicolumn{2}{|l|}{ Natural causes. } & $0(0 \%)$ & $2(5 \%)$ \\
\hline \multicolumn{2}{|l|}{ Deforestation. } & $1(3 \%)$ & $0(0 \%)$ \\
\hline \multicolumn{2}{|l|}{ Overexploitation of natural resources. } & $2(5 \%)$ & $0(0 \%)$ \\
\hline \multirow{2}{*}{ Effects } & Melting icecaps. & $3(8 \%)$ & $0(0 \%)$ \\
\hline & Temperature rise. & $3(8 \%)$ & $2(5 \%)$ \\
\hline \multirow{2}{*}{ Other problems } & Acid rain. & $0(0 \%)$ & $3(8 \%)$ \\
\hline & Destruction of the ozone layer. & $1(3 \%)$ & $7(18 \%)$ \\
\hline \multicolumn{2}{|l|}{ Don't know/no answer. } & $2(5 \%)$ & $2(5 \%)$ \\
\hline
\end{tabular}

When comparing the pre-test and post-test results, an increase of $30 \%$ is observed in the use of the element of explanation whereby the cause of climate change is the increase in the greenhouse effect. Moreover, deforestation continued to be one of the anthropic causes less related to climate change. This may be because students tend not to conceive trees as carbon sinks. In addition, after instruction, more students referred to other environmental problems not directly related to climate change as causes, such as acid rain or the destruction of the ozone layer. This might be because when the teacher addressed the major environmental problems in the atmosphere, she did not stress enough to distinguish the enhanced greenhouse effect, the ozone depletion and the acid rain. Moreover, the textbook helped to reinforce these misconceptions by presenting these environmental problems under the same heading as a whole.

As far as previous research is concerned, it is observed that the finding regarding pollution in general as a cause of climate change is aligned with the results of other studies (Andersson and Wallin 2000; Authors 2012; Punter et al. 2011). In the students' textbook, the enhanced greenhouse effect was represented by images 
This is a post-peer-review, pre-copyedit version of an article published inResearch in Science Education. The final authenticated version is available online at: https://doi.org/10.1007/s11165-018-9703-1

that included factories discharging air pollutants into the atmosphere. We agree with Shepardson et al. (2011a) that this implies that air pollution in general is considered as the main cause of the enhanced greenhouse effect. Our results also support the findings of Chang and Pascua (2016), since other activities with a high weight in greenhouse gases emissions, such as livestock, were not mentioned by the students.

Question 3: Are the Greenhouse Effect and Climate Change the Same Thing? From the students' answers, we have generated three main categories: no, yes and don't know/no answer (Table 6). The no category was divided into several subcategories since some students' answers contain only the adverb no, while other students' answers contained more or less appropriate explanations.

Table 6 shows that only $10 \%$ of $7^{\text {th }}$ grade students (12-13 years) gave answers in the pre-test in which they correctly related the enhanced greenhouse effect to climate change. This percentage rose to $33 \%$ after instruction, while the percentage of students who stated that climate change is caused by the greenhouse effect decreased by $18 \%$. This fact suggests that the instruction helped students to understand the greenhouse effect as a natural phenomenon essential for maintaining life on the planet. Some students, both before and after instruction, wrongly related the greenhouse effect to the destruction of the ozone layer.

Table 6 Frequency and percentage of references to the different elements of explanation in the answers to the question: Are the greenhouse effect and climate change the same thing? $(\mathrm{N}=40)$

\begin{tabular}{|c|c|c|c|c|}
\hline \multicolumn{2}{|l|}{ Categories } & Examples & $\begin{array}{l}7^{\text {th }} \text { grade } \\
\text { (12-13 years) } \\
\text { Pre-test }\end{array}$ & $\begin{array}{l}7^{\text {th }} \text { grade } \\
\text { (12-13 years) } \\
\text { Post-test }\end{array}$ \\
\hline \multirow[t]{3}{*}{ No. } & & - & $38(95 \%)$ & $36(90 \%)$ \\
\hline & $\begin{array}{l}\text { Relationship between the enhanced } \\
\text { greenhouse effect and climate } \\
\text { change (right answer). }\end{array}$ & $\begin{array}{l}\text { No, the greenhouse effect is a } \\
\text { natural cause and its increase } \\
\text { is causing climate change } \\
\text { (post-test, student } 6 \text { ). }\end{array}$ & $4(10 \%)$ & $13(33 \%)$ \\
\hline & $\begin{array}{l}\text { Partial definition of the natural } \\
\text { greenhouse effect, but it is not }\end{array}$ & $\begin{array}{l}\text { No, the greenhouse effect is the } \\
\text { Earth's ability to retain part of }\end{array}$ & $10(25 \%)$ & $10(25 \%)$ \\
\hline
\end{tabular}


related to climate change correctly (partially right answer). the radiation, whereas climate

change is the change in temperature, rainfall... (pretest, student 27).

The greenhouse effect No, because the greenhouse causes climate effect is what creates climate change.

The greenhouse effect is caused by climate change. change (pre-test, student 10).

No, because the greenhouse effect is caused by climate change (pre-test, student 21).

No, because climate change is when the temperature rises or falls and the greenhouse effect is caused by pollution, which makes holes in the ozone layer and causes more solar radiation (pre-test, student 1).

Wrong The greenhouse effect answer. is related to the ozone layer.

The greenhouse effect is related to $\mathrm{UV}$ radiation.

No, the greenhouse effect is what prevents ultraviolet rays from colliding with the Earth (pre-test, student 37).

$9(23 \%)$

Others.

\begin{tabular}{|c|c|c|c|}
\hline Others. & $\cdot$ & $6(15 \%)$ & $6(15 \%)$ \\
\hline No explanation given. & - & $5(13 \%)$ & $1(3 \%)$ \\
\hline Yes & - & $2(5 \%)$ & $1(3 \%)$ \\
\hline Don't know/no answer & - & 0 & $2(5 \%)$ \\
\hline
\end{tabular}

Question 4: Diagram of the Greenhouse Effect Table 7 shows the elements of explanation used by students for their diagrams of the greenhouse effect. With the exception of the category labelled as water vapour, all others were taken or adapted in interaction with data from previous studies (Authors 2012; Shepardson et al. 2011a).

From the results obtained in this study, it is observed that in the pre-test, $88 \%$ of students represented solar radiation, $25 \%$ included an unidentified layer, $40 \%$ drew a layer explicitly identified with a layer of gases, $38 \%$ represented retained heat, and $38 \%$ included the radiation emitted back towards the Earth.

In the post-test, some participants included infrared radiation in their drawings (40\%) and there was a significant increase in the explanation that involved the idea whereby part of the radiation emitted back from the surface managed to get through the atmosphere and was lost in space. This improvement after instruction might be due to the fact that the teacher used during her classes a video that included several diagrams about the mechanism of the greenhouse effect in which a distinction was made between infrared radiation, ultraviolet radiation and visible light. Moreover, in the post-test, some students referred explicitly to greenhouse gases (18\%). However, a relatively high percentage of students $(43 \%)$ continued to incorporate a layer in their drawings of the greenhouse effect. Although the teacher mentioned during the classes that the greenhouse gases are evenly distributed in the atmosphere rather than forming a layer, it seems that the diagrams included in the 
This is a post-peer-review, pre-copyedit version of an article published inResearch in Science Education. The final authenticated version is available online at: https://doi.org/10.1007/s11165-018-9703-1

video and textbook showing the existence of a greenhouse gas layer above the Earth's surface that traps and reflects the sun's energy might reinforce the students' misconceptions about this phenomenon (Harris and Gold 2017; Shepardson et al. 2011a).

Table 7 Frequency and percentage of references to different elements of explanation in the answers to the question: Drawing of the greenhouse effect $(\mathrm{N}=40)$

$\begin{array}{lll} & & \\ \text { Categories } & 7^{\text {th }} \text { grade } & 7^{\text {th }} \text { grade } \\ & (12-13 \text { years }) & (12-13 \text { years }) \\ \text { Post-test }\end{array}$

Comparing the results of this study with those of previous research on climate change, it is worth mentioning that the idea of a layer of gases that traps solar radiation also appears frequently in other papers (Andersson and Wallin 2000; Koulaidis and Christidou 1999; Pruneau et al. 2003). In addition, similar to previous studies (Andersson and Wallin 2000; Kilinç et al. 2008; Shepardson et al. 2011a), before instruction few student distinguished between types of solar energy, with most referring only to the sun's rays.

Question 5: What Actions do You Suggest to Slow Down Climate Change? Table 8 shows the categories generated from the analysis of the answers regarding the actions proposed by students to mitigate climate change. With the exception of the categories labelled as reducing production in factories, not throwing rubbish into rivers and seas, and reduce CGC emissions, all the others were taken or adapted in interaction with data from previous studies (Boyes et al. 2009; Chhokar et al. 2011; Authors 2012; Papadimitriou 2004). From the results obtained in this study, it is noted that a large proportion of students in the pre-test and post-test suggested a reduction of vehicle use and proposed increasing the use of public transport and cycling or walking short distances $(45 \%)$. A high percentage of students $(30 \%)$ also mentioned more generic actions, such as not polluting the environment. The suggestion of this action is coherent with the results obtained from the other 
This is a post-peer-review, pre-copyedit version of an article published inResearch in Science Education. The final authenticated version is available online at: https://doi.org/10.1007/s11165-018-9703-1

questions in the questionnaire, where the $7^{\text {th }}$ graders referred mainly to pollution as a cause of climate change. After instruction, we also observed a significant increase in the number of references to energy-saving measures in the home and responsible energy consumption, 50\% compared to the 5\% of the pre-test. However, actions such as not cutting down trees were hardly mentioned because, as we saw in the analysis of the third question, deforestation is poorly related to climate change.

As for previous research, the finding referred to a reduction of vehicle use as the main action to slow down climate change is consistent with the literature (Bodzin et al. 2014). However, unlike other studies (Authors 2012; Punter et al. 2011), there were few students who suggested reducing gases emissions such as $\mathrm{CO}_{2}$, the main anthropogenic greenhouse gas.

Table 8 Frequency and percentage of references to different elements of explanation in the answers to the question: What actions do you suggest to slow down climate change? $(\mathrm{N}=40)$

\begin{tabular}{|c|c|c|c|}
\hline \multicolumn{2}{|l|}{ Categories } & $\begin{array}{l}7^{\text {th }} \text { grade } \\
\text { (12-13 years) }\end{array}$ & $\begin{array}{l}7^{\text {th }} \text { grade } \\
\text { (12-13 years) }\end{array}$ \\
\hline \multirow[t]{2}{*}{ No answer. } & & $2(5 \%)$ & $3(8 \%)$ \\
\hline & Reduce $\mathrm{CO}_{2}$ emissions. & $3(8 \%)$ & $3(8 \%)$ \\
\hline \multirow{3}{*}{ Gases } & Reduce GHG emissions. & $0(0 \%)$ & $1(3 \%)$ \\
\hline & Reduce gas emissions. & $5(13 \%)$ & $2(5 \%)$ \\
\hline & Reduce CFC emissions and aerosols. & $1(3 \%)$ & $8(20 \%)$ \\
\hline \multirow{4}{*}{ Energy } & Reduce consumption of fossil fuels. & $4(10 \%)$ & $0(0 \%)$ \\
\hline & Increase consumption of renewable energy. & $3(8 \%)$ & $3(8 \%)$ \\
\hline & $\begin{array}{l}\text { Reduce the use of cars (using public transport, bicycles, } \\
\text { electric cars, walking). }\end{array}$ & $18(45 \%)$ & $25(63 \%)$ \\
\hline & Save energy, responsible and efficient consumption. & $2(5 \%)$ & $20(50 \%)$ \\
\hline \multirow{6}{*}{ Others } & $\begin{array}{l}\text { Generic actions, such as not polluting the environment or } \\
\text { being more careful with the environment. }\end{array}$ & $12(30 \%)$ & $4(10 \%)$ \\
\hline & Not cutting down trees. Planting trees. & $4(10 \%)$ & $6(15 \%)$ \\
\hline & Not throwing rubbish into rivers and seas. & $2(5 \%)$ & $1(3 \%)$ \\
\hline & Recycling. & $5(13 \%)$ & $5(13 \%)$ \\
\hline & $\begin{array}{l}\text { Reducing the use of or not using products that damage the } \\
\text { ozone layer. }\end{array}$ & $1(3 \%)$ & $0(0 \%)$ \\
\hline & Reducing production in factories. & $3(8 \%)$ & $3(8 \%)$ \\
\hline
\end{tabular}

\section{Results and Discussion of the Second Analysis: Mental Models}

The following describes the four levels taken from the students' mental models on the greenhouse effect. The levels are constructions that aim to represent the most important characteristics of the models. As in the Koulaidis and Christidou (1999) study, the description of each level in Table 9 is accompanied by a diagram representing graphically the main elements of the models in the level. The levels have been numbered 1 to 4 in 
This is a post-peer-review, pre-copyedit version of an article published inResearch in Science Education. The final authenticated version is available online at: https://doi.org/10.1007/s11165-018-9703-1

increasing order of sophistication, with a view to showing a progression in students' learning on the greenhouse effect.

Table 9 Description of the levels in the mental models of the $7^{\text {th }}$ grade students on the greenhouse effect Description of the level Diagram

This level groups descriptive models in which no operating mechanisms are shown. For this reason, it is considered the lowest level of sophistication. Climate change is related to the increase in temperature of the Earth, but no reference is made to what the greenhouse effect is. This level also includes the models in which students present the idea that the greenhouse effect causes changes to the weather and the mechanism that regulates daytime and night-time temperatures.

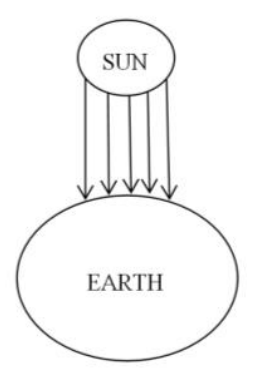

This level includes the models that offer the idea whereby the destruction of the ozone layer and the ozone hole caused by 2 pollution let more solar radiation reach the Earth and heat it up, or whereby pollution thickens the ozone layer, preventing solar radiation from being emitted back into space.



This level includes the models with the idea that there are greenhouse gases that are emitted into the atmosphere and trap heat. It also includes the idea of a layer of gases that surrounds the Earth. To reduce climate change, students suggest reducing gas emissions. The models grouped at this level are more sophisticated than those included in Level 2 because students recognise the existence of greenhouse gases, claiming they are the culprits of global warming.

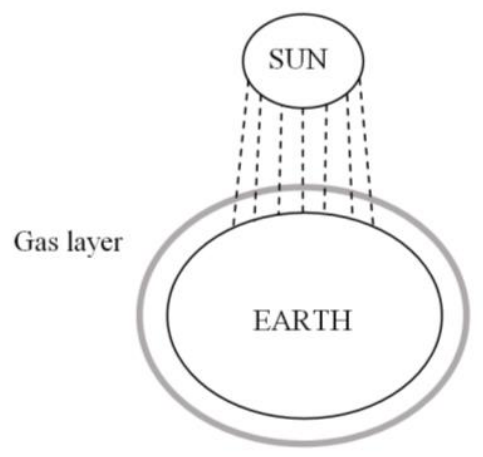

This level grouped together the models including the idea that greenhouse gases absorb part of the radiation emitted by the Earth, preventing it from being completely emitted into space. Unlike the models on Level 3, the models on this level include

4 the idea that greenhouse gases are evenly distributed in the atmosphere, rather than being concentrated in one layer. This is considered the highest level of sophistication because it groups models very close to the school science model of the greenhouse effect.




The models in Level 1 are purely descriptive and similar to what Reinfried and Tempelmann (2014) called 'isolated pieces of knowledge'. The models in levels 2 and 3 include a mechanism that is consistent with the causes and effects of and strategies for mitigating climate change, even though they are alternative explanatory models to the conceptual model of the greenhouse effect. According to Level 2, pollution causes ozone depletion or formation which allows more of the sun's rays to reach the Earth or causes the sun's rays to be trapped. Models in Level 2 are comparable to the Model 2 identified by Shepardson et al. (2011a, 2017) and the model described by Reinfried and Tempelmann (2014) as 'increasing heat input'. The model E reported in the study of Koulaidis and Christidou (1998) and the Ozone model described by Harris and Gold (2017) also adapt to Level 2. As far as Level 3 is concerned, greenhouse gases trap the sun's rays, heating the Earth's surface. This level also includes the idea of a layer of gases that surrounds the Earth. Models in this level are similar to the Model 4 described by Shepardson et al. (2011a, 2017). The mental models in Level 4 are the ones closer to the school science model of the greenhouse effect.

Table 10 shows the frequencies of each level of sophistication in the students' mental models in the pretest and post-test. We observe that before instruction, the most frequent level was Level 1 (48\%) Students in Level 1 refer to pollution as the cause of climate change and the measures they give to slow down climate change include reducing the use of private cars and not polluting. 18\% of students held models in Level 2 before instruction. Students with models in Level 2 confuse and fuse ideas related to the ozone depletion and greenhouse effect, so to reduce climate change they suggest reducing emissions of gases that affect the ozone layer. $23 \%$ of students run models in Level 3 before instruction. Students with models in Level 3 assume that greenhouse gases cause greenhouse effect, but they don't understand that these gases are evenly distributed in the atmosphere. Only 5\% of students held models in Level 4 before instruction. Students with models in Level 4 tend to more easily distinguish the visible radiation from the Sun and the infrared radiation emitted by the Earth. Students with models in Level 4 also tend to recognise that not all the radiation is emitted back to Earth, but that part of it is emitted into space. After instruction, the most representative level was Level 3 (38\%). The highest level of sophistication held the second place, with a quarter of students exhibiting models in Level 4 after the teaching unit.

Table 10 Ratio of $7^{\text {th }}$ grade students associated with each level in the mental models and frequency of each level $(\mathrm{N}=40)$

\begin{tabular}{cll}
\hline Level of sophistication & Number of students pre-test & Number of students post-test \\
\hline 1 & $19(48 \%)$ & $9(23 \%)$ \\
2 & $7(18 \%)$ & $6(15 \%)$
\end{tabular}


This is a post-peer-review, pre-copyedit version of an article published inResearch in Science Education. The final authenticated version is available online at: https://doi.org/10.1007/s11165-018-9703-1

$\begin{array}{lll}3 & 9(23 \%) & 15(38 \%) \\ 4 & 5(13 \%) & 10(25 \%)\end{array}$

Fig. 1 shows a chart representing shifts in students' mental models on the greenhouse effect before and after instruction. This type of chart provides more information than a conventional one, indicating students who shifted their models on the greenhouse effect after instruction and reflecting towards which new model the change occurred (Harris and Gold 2017). For example, eight students remained at Level 1 both the pre and posttest, and two students who held a model in Level 1 shifted to a model in Level 2 after instruction.

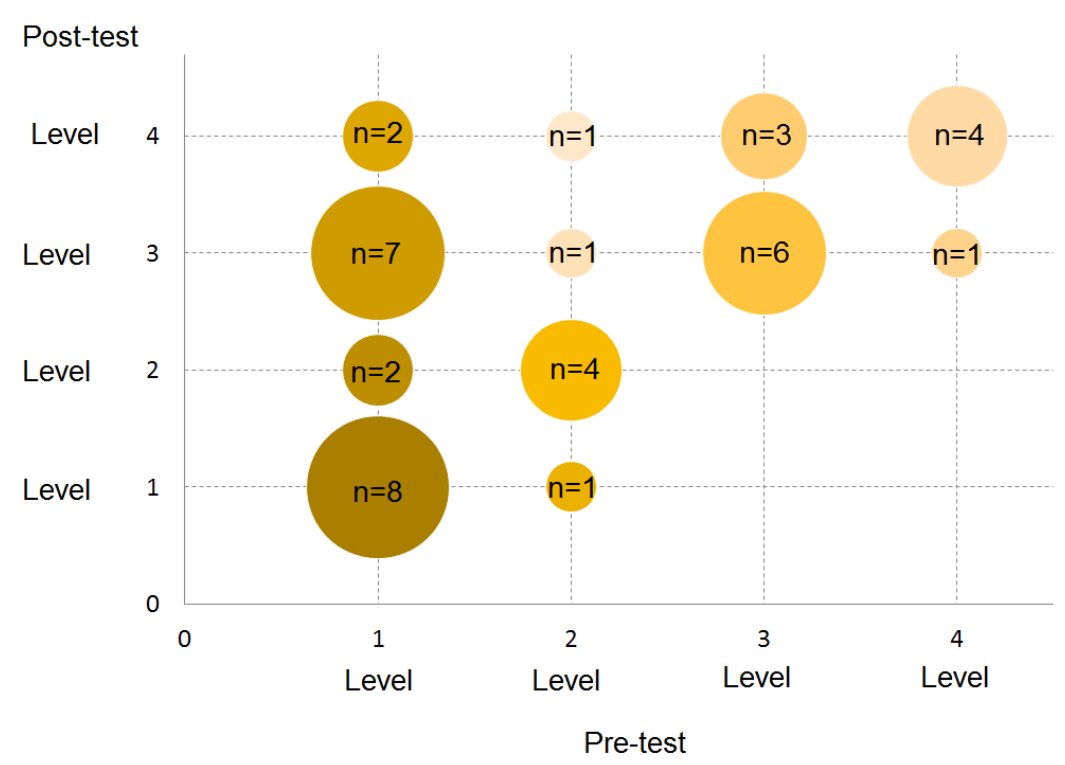

Fig. 1 Evolution of the levels in the mental models of $7^{\text {th }}$ grade students on climate change before and after instruction. Each circle represents the level of the mental model before (horizontal axis) and after (vertical axis) the teaching activity. The circles on the diagonal represent the students who, to interpret the greenhouse effect, applied a model on the same level of sophistication throughout the study. The size of the circles indicates in each case the number of students whose model is on that level

From Fig. 1 we can see that 22 students (55\%) remained at the same level before and after instruction. This might be because during instruction, insufficient emphasis was placed on students being aware of their initial models and there were few opportunities to confront these models with the models of school science. Seven students (18\%) evolved from Level 1 to Level 3. Two participants (5\%) evolved from Level 1 to Level 4 , moving on from a level grouping together merely descriptive models to the highest level of sophistication. The data also show that four students who used models assigned to Level 2, which associate the greenhouse effect with the ozone layer, do not change model despite important conceptual errors. This is probably because, as already stated in numerous studies, they are extremely practical for students, allowing them to explain the causes and consequences of climate change (Authors 2012; Reinfried and Tempelmann 2014). 


\section{Conclusions and Implications for Education}

Most of the previous studies which address the important topic of students' mental models of climate change and the greenhouse effect refer to understanding before instruction. Authors such as Rickinson (2001) noted that there are few studies dealing with students' mental models, and Shepardson et al. (2009) insisted on the need to conduct more researchers to gain a better understanding of how students develop their models on climate change. Therefore, this study represents a new contribution to the area of science education, describing the ideas and levels of sophistication of students' mental models on the greenhouse effect and climate change, both before and after instruction.

With regard to the first research question that refers to students' alternative ideas on climate change and greenhouse effect, the explanations offered showed that after instruction, some of the students wrongly associated this environmental problem with the reduction of the ozone layer, an idea already discussed in previous studies (Andersson and Wallin 2000; Boyes and Stanisstreet 1993; Francis et al. 1993; Authors 2012; Punter et al. 2011). From the results of our study we observed that this type of alternative ideas might be reinforced by textbooks or teachers' explanations that deal with different environmental problems such as the acid rain, ozone depletion and the enhanced greenhouse effect as a single set. When tackling environmental problems, a greater emphasis should be placed on clarifying the causes and the mechanism of ozone depletion and global warming.

As causes of climate change, students gave, even after instruction, generic answers, mostly using pollution as an element of explanation, where these results coincide with those of Gómez-Granell and CerveraMarch (1993). This finding can be attributed to the fact that students know that this phenomenon takes places in the atmosphere, but they don't understand the mechanism. Moreover, according to Shepardson et al. (2011a), the factories included in the diagrams found in textbooks that represent the mechanism of the greenhouse effect might contribute to the idea that pollution in general causes climate change.

In addition, the answers students gave to suggest actions to mitigate climate change revealed that they do not have a clear understanding of the prevention and correction measures for solving this environmental problem. Indeed, in the pre-test, certain apparently obvious measures, such as energy-saving in homes or reducing GHG emissions, were hardly mentioned or not mentioned at all. However, measures such as recycling waste have been mentioned, both before and after instruction. This leads us to consider the reflection made previously by 
Punter et al. (2011) whereby it is necessary to consider whether students are really knowledgeable about the emission of greenhouse gases associated with the management of solid waste or simply confuse this environmental problem with climate change.

With regard to the second research question that seeks to know at what levels of sophistication are the students' mental models on climate change and the greenhouse effect, we observed that most students (48\%) held models in Level 1 before instruction. In this Level that corresponds with the lowest level of sophistication, there is no mechanism to explain the greenhouse effect. Almost a quarter of the students (23\%) showed models in Level 3 before instruction. Students in this level claim that greenhouse gases are emitted into the atmosphere and trap heat, but they consider that these gases are concentrated forming a layer in the atmosphere.

With regard to the third research question that refers to the differences between the students' mental models on climate change before and after instruction, we observed a certain evolution to other more sophisticated models after instruction. After instruction and for the first time, a high percentage of students included the infrared radiation in their representations of the greenhouse effect's mechanism, and some of them distinguished between this radiation and ultraviolet radiation. This demonstrates that a distinction between sunlight and terrestrial radiation helps students to conceptualize the wave model, essential for students to construct a scientific model of the greenhouse effect (Harris and Gold 2017; Ratinen et al. 2013).

From the results of this study we can conclude that the descriptive models associated with Level 1 are likely to be modified and evolve towards the models of school science. Moreover, as we note in the introduction of the paper when we describe conceptual change from the perspective of mental mode ls, this evolution would not constitute a conceptual change in terms of Chi (2008). Students who exhibit models assigned to Level 1, have a very limited previous knowledge concerning greenhouse effect. As a consequence, they reconstruct their mental models by assimilating new information into the existing knowledge structures. Something similar happens in the evolution of the models in Level 3 towards the highest level of sophistication. Models in which greenhouse gases are concentrated in a layer in the atmosphere seem to be easily modified (Harris and Gold 2017). The idea of greenhouse gases as the culprits of the greenhouse effect already exists and students simply have to learn that these gases are evenly distributed in the atmosphere rather than forming a layer. As Chi (2008) state, adding and gap-filling a mental model constitute enrichment. However, the evolution of models assigned to Level 2 towards the models of school science would constitute a conceptual change considering the ideas of Chi (2008). The existing differences between their previous conceptions and the new information are so 
This is a post-peer-review, pre-copyedit version of an article published inResearch in Science Education. The final authenticated version is available online at: https://doi.org/10.1007/s11165-018-9703-1

profound that students have to construct a completely different mental model in order to understand greenhouse effect (Reinfried and Tempelmann 2014). This change is apparently more difficult to achieve due to it implies a modification in its highly coherent and extremely functional initial mental model (Francis et al. 1993; Authors 2012; Reinfried and Tempelmann 2014).

Therefore, a mental model can be descriptive, similar to what Reinfried and Tempelmann (2014) call 'isolated pieces of knowledge'. These types of models that correspond to the lowest level of sophistication are constituted by single ideas and are easier to transform towards the model of school science. In other cases, models are identified in which these single ideas or 'isolated pieces of knowledge' are interconnected with other ideas. Some of these ideas might be alternative ideas, so that when students mentally run their models to predict and explain phenomena, inappropriate conclusions and new alternative ideas are generated. When these alternative models are extremely coherent and have a high personal explanatory value, their change towards the model of school science is difficult to achieve (Authors 2012; Reinfried and Tempelmann 2014).

Another aspect that is important to note is that $55 \%$ of students remained at the same level before and after instruction, with many students at the lowest level of sophistication. This might be because during instruction the teacher presented the correct knowledge, but the alternative models were not addressed correctly. During the teaching unit, insufficient emphasis was placed on students being aware of their initial models and there were few opportunities to confront their models with the model of school science. The students just covered the pre-test individually and then handed it to the teacher, without discussing the students' answers. Thus, the students couldn't be aware of their alternative models on climate change.

According to Chang and Pascua (2016), an appropriate understanding of the processes involved in climate change constitute a key factor for students intelligently take actions in response to the challenges posed by global warming. By this reason, it's highly necessary to students have an accurate understanding about climate change and construct mental models as close to the model of school science as possible. Given the above, we consider it recommendable for teachers to bear in mind students' mental models and alternative ideas to improve teaching and learning processes. As Dawson (2015) points out, knowledge of students' models makes it possible to use teaching strategies and develop appropriate teaching resources to remove persistent misconceptions from students' representations. For example, if a widely spread idea among our students is that greenhouse gases constitute a layer in the atmosphere, we should avoid the use of teaching materials that reinforce models such as type 3 and address the distribution of greenhouse gases in the atmosphere (Harris and 
This is a post-peer-review, pre-copyedit version of an article published inResearch in Science Education. The final authenticated version is available online at: https://doi.org/10.1007/s11165-018-9703-1

Gold 2017). Strickhouser et al. (2017) suggest that using experiments and simulations in which the mechanism of greenhouse gases is visible also help students to better understand climate change. It is therefore necessary to create situations in the classroom that allow students to make explicit their ideas and mental models, and compare their validity through discussion with teachers and other students. Strickhouser et al. (2017) claim that guided discussions where the teacher interacts with students help them to construct more scientific explanations on climate change. As Gutiérrez (1994) reiterate, students won't modify their models unless they perceive that their mental representations don't satisfy the conditions of consistency, robustness and correspondence. The development of mental models requires instruction and curricular materials that stimulate students' use of conceptual and physical models as tools for refining their mental models (Shepardson et al. 2017). It is important to bear in mind that changing students' mental models is typically a long, nonlinear and complex process that involves steps forwards and backwards and it is strongly determined by emotional and social issues (Duit and Treagust 2003).

As the limitations of the study, it must be made clear that it does not seek to generalise results to other cases due to the qualitative nature of the research involving a small sample size. However, this study does allow for comparisons with other studies of a similar nature, contributing to the knowledge of students' conceptions and mental models on climate change and the educational implications proposed to solve the difficulties in learning about this environmental problem.

In the $21^{\text {st }}$ century environmental education is crucial for students and public at large to understand why the greenhouse effect and climate change occur. This is the first step to understand what kind of things we can do or stop doing in order to slow down climate change. We hope that this work will help to get a better understanding of students' mental models about these environmental issues with the aim of bringing students' models closer to the models of school science.

\section{Compliance with Ethical Standards}

Informed Consent Informed consent was obtained from all individual participants included in the study.

Ethical Standard All procedures performed in studies involving human participants were in accordance with the ethical standards of the institutional and/or national research committee and with the 1964 Helsinki declaration and its later amendments or comparable ethical standards.

\section{References}


This is a post-peer-review, pre-copyedit version of an article published inResearch in Science Education. The final authenticated version is available online at: https://doi.org/10.1007/s11165-018-9703-1

Andersson, B., \& Wallin, A. (2000). Students' understanding of the greenhouse effect, the societal consequences of reducing $\mathrm{CO}_{2}$ emissions and the problem of ozone layer depletion. Journal of Research in Science Teaching, 37(10), 1096-1111. doi: 10.1002/1098-2736(200012)37:10<1096::AIDTEA4>3.0.CO;2-8

Anyanwu, R., Le Grange, L., \& Beets, P. (2015). Climate change science: the literacy of geography teachers in the Western Cape province, South Africa. South African Journal of Education, 35(3), 1-9. doi: 10.15700/SAJE.V35N3A1160

Arto, M., \& Meira, P. A. (2011). Cuéntaselo a Gurb. El cambio climático y las ideas previas [Tell it to Gurb. Climate change and previous ideas]. In P.A. Meira (Ed.), Conoce y valora el cambio climático. Propuestas para trabajar en grupo (pp. 17-23). Santiago de Compostela: Mapfre.

Aydin, F., \& Coşkun, M. (2010). Global warming' perceptions of primary education 7th grade students in Turkey. World Applied Sciences Journal, 10(4), 426-432.

Berkowitz, A. R., Ford, M. F., \& Brewer, C. A. (2005). A framework for integrating ecological literacy, civics literacy and environmental citizenship in environmental education. In E. A. Johnson, M. J. Mappin (Eds.), Environmental education and advocacy: Changing perspectives of ecology and education (pp. 227-266). New York: Cambridge University Press.

Bodzin, A. M., Anastasio, D., Sahagian, D., Peffer, T., Dempsey, C., \& Steelman, R. (2014). Investigating climate change understandings of urban middle-level students. Journal of Geoscience Education, 62(3), 417-430. doi: 10.5408/13-042.1

Bofferding, L., \& Kloser, M. (2015). Middle and high school students' conceptions of climate change mitigation and adaptation strategies. Environmental Education Research, 21(2), 275-294. doi. $10.1080 / 13504622.2014 .888401$

Boyes, E., \& Stanisstreet, M. (1993). The greenhouse effect: Children's perception of causes, consequences and cures. International Journal of Science Education, 15(5), 531-552.

Bybee, R. W. (1993). Reforming Science Education. Social Perspectives \& Personal Reflections. New York: Teachers College Press.

Chang, C., \& Pascua, L. (2016). Singapore students' misconceptions of climate change. International Research in Geographical and Environmental Education, 25(1), 84-96. doi: 10.1080/10382046.2015.1106206 
Chhokar, K., Dua, S., Taylor, N., Boyes, E., \& Stanisstreet, M. (2011). Indian secondary students' views about global warming: Beliefs about the usefulness of actions and willingness to act. International Journal of Science and Mathematics Education, 9(5), 1167-1188. doi: 10.1007/s10763-010-9254-z

Chi, M. T. H. (2008). Three types of conceptual change: Belief revision, mental models transformation, and categorical shift. In S. Vosniadou (Ed.), Handbook of research on conceptual change (pp. 6182). Hillsdale, NJ: Erlbaum.

Christensen, R., \& Knezek, G. (2015). The climate change attitude survey: Measuring middle school student beliefs and intentions to enact positive environmental change. International Journal of Environmental and Science Education, 10(5), 773-788.

Dawson, V. (2015). Western Australian high school students' understandings about the socioscientific issue of climate change. International Journal of Science Education, 37(7), 1024-1043. doi: $10.1080 / 09500693.2015 .1015181$

Duit, R. (2009). Bibliography STCSE: Students' and teachers' conceptions and science education. Kiel, Germany: University of Kiel.

Duit, R., \& Treagust, D. P. (2003). Conceptual change: A powerful framework for improving science teaching and learning. International Journal of Science Education, 25(6), 671-688. doi: $10.1080 / 09500690305016$

Dyball R., Brown, V. A., \& Kenn, M. (2007). Towards sustainability: Five strands of social learning. In A. E. J. Wals (Ed.), Social learning towards a sustainable world (pp. 181-194). The Netherlands: Wageningen Academic Publishers.

Fernández, G., González, G., \& Molina, J. L. (2011). El cambio climático y el agua: Lo que piensan los universitarios [Climate change and water: What undergraduates think]. Enseñanza de las ciencias: Revista de investigación y experiencias didácticas, 29(3), 427-438.

Fisher, B. (1998). Australian students' appreciation of the Greenhouse effect and the ozone hole. Australian Science Teachers Journal, 44(3), 46-55.

Francis, C., Boyes, E., Qualter, A., \& Stanisstreet, M. (1993). Ideas of elementary students about reducing the “Greenhouse Effect”. Science Education, 77(4), 375-392.

Gadgil, S., Nokes-Malach, T. J., \& Chi, M. T. H. (2012). Effectiveness of holistic mental model confrontation in driving conceptual change. Learning and Instruction, 22(1), 47-61. 
This is a post-peer-review, pre-copyedit version of an article published inResearch in Science Education. The final authenticated version is available online at: https://doi.org/10.1007/s11165-018-9703-1

Gilbert, J. K., \& Boulter, C. J. (2000). Developing models in Science Education. Dordrecht: Kluwer.

Goldman, D., Yavetz, B., Pe'er, S. (2014). Student teachers' attainment of environmental literacy in relation to their discipline major during undergraduate studies. International Journal of Environmental \& Science Education, 9(4), 369-383. doi: 10.12973/ijese.2014.222a

Gómez-Granell, C., \& Cervera-March, S. (1993). Development of conceptual knowledge and attitudes about energy and environment. International Journal of Science Education, 5(15), 553-565. doi: $10.1080 / 0950069930150508$

Greca, I. M., \& Moreira, M. A. (2000). Mental models, conceptual models, and modelling. International Journal of Science Education, 22(1), 1-11. doi: 10.1080/095006900289976

Groves, F. H., \& Pugh, A. F. (1999). Elementary pre-service teacher perceptions of the greenhouse effect. Journal of Science Education and Technology, 8(1), 75-81. doi: 10.1023/A:1009433705790

Gutiérrez, R. (1994). Coherencia del pensamiento espontáneo y causalidad. El caso de la dinámica elemental [Coherency of spontaneous thinking and causality. The case of elemental dynamics] (Doctoral thesis). Complutense University of Madrid, Madrid.

Gutiérrez, R. (2004). La modelización y los procesos de enseñanza/aprendizaje [Modelling and teaching/learning processes]. Alambique: Didáctica de las Ciencias Experimentales, 10(42), 8-18.

Harris, S. E., \& Gold, A. U. (2017). Learning molecular behavior may improve student explanatory models of the greenhouse effect. Environmental Education Research, 1-18. doi: 10.1080/13504622.2017.1280448

Intergovernmental Panel on Climate Change (IPCC) (2014). Climate change 2014: Synthesis report. Contribution of working groups I, II and III to the fifth assessment report of the Intergovernmental Panel on Climate Change. Geneva, Switzerland: IPCC.

Jickling, B., \& Wals, E. J. (2008). Globalization and environmental education: Looking beyond sustainable development. Journal of Curriculum Studies, 40(1), 1-21. doi: 10.1080/00220270701684667

Jones, N. A., Ross, H., Lynam, T., Perez, P., \& Leitch, A. (2011). Mental models: An interdisciplinary synthesis of theory and methods. Ecology and Society, 16(1), 46.

Karpudewan, M., Roth, W. M., \& Abdullah, M. N. S. B. (2015). Enhancing primary school students' knowledge about global warming and environmental attitude using climate change activities. International Journal of Science Education, 37(1), 31-54. doi: 10.1080/09500693.2014.958600 
This is a post-peer-review, pre-copyedit version of an article published inResearch in Science Education. The final authenticated version is available online at: https://doi.org/10.1007/s11165-018-9703-1

Karpudewan, M., Roth, W. M., \& Chandrakesan, K. (2014). Remediating misconception on climate change among secondary school students in Malaysia. Environmental Education Research, 21(4), 631-648. doi: $10.1080 / 13504622.2014 .891004$

Kilinç, A., Stanisstreet, M., \& Boyes, E. (2008). Turkish students' ideas about global warming. International Journal of Environmental and Science Education, 3(2), 89-98.

Klosterman, M. L., \& Sadler, T. D. (2010). Multi-level assessment of scientific content knowledge gains associated with socioscientific issues-based instruction. International Journal of Science Education, 32(8), 1017-1043. doi: 10.1080/09500690902894512

Koulaidis, V., \& Christidou, V. (1999). Models of students' thinking concerning the greenhouse effect and teaching implications. Science Education, 83(5), 559-576.

Liarakou, G., Athanasiadis, I., \& Gavrilakis, C. (2011). What Greek secondary school students believe about climate change? International Journal of Environmental and Science Education, 6(1), 79-98.

McGinnis, J. R., Breslyn, W., McDonald, R. C., \& Hestness, E. (2017). Supporting the inclusion of climate change in U.S. science education curricula by use of learning progressions. In D. P Shepardson, A. Roychoudhury, A. S. Hirsch (Eds.), Teaching and learning about climate change (pp. 135-152). New York: Routledge.

Meadows, G., \& Wiesenmayer, R. L. (1999). Identifying and addressing students' alternative conceptions of the causes of global warming: The need for cognitive conflict. Journal of Science Education and Technology, 8(3), 235-239. doi: 10.1023/A:1009412414470

Miller, H. K., \& Anderson, C. W. (2017). Using next generation science standards' crosscutting concepts as a tool for climate change and citizenship education. In D. P Shepardson, A. Roychoudhury, A. S. Hirsch (Eds.), Teaching and learning about climate change (pp. 181-193). New York: Routledge.

Mohan, L., Chen, J., \& Anderson, C. W. (2009). Developing a multi-year learning progression for carbon cycling in socio-ecological systems. Journal of Research in Science Teaching, 46(6), 675-698. doi: $10.1002 /$ tea. 20314

Oliva, J. M. (1999). Algunas reflexiones sobre las concepciones alternativas y el cambio conceptual [Some reflections on alternative conceptions and conceptual change]. Enseñanza de las Ciencias, 17(1), 93107. 
This is a post-peer-review, pre-copyedit version of an article published inResearch in Science Education. The final authenticated version is available online at: https://doi.org/10.1007/s11165-018-9703-1

Papadimitriou, V. (2004). Prospective primary teachers' understanding of climate change, greenhouse effect, and ozone layer depletion. Journal of Science Education and Technology, 13(2), 299-307. doi: 10.1023/B:JOST.0000031268.72848.6d

Patton, M.Q. (2002). Qualitative research and evaluation. Thousand Oaks, CA: Sage.

Posner, G. J., Strike, K. A., Hewson, P. W., \& Gertzog, W. A. (1982). Accomodation of a scientific conception: toward a theory of conceptual change. Science Education, 66(2), 211-227.

Pruneau, D., Gravel, H., Bourque, W., \& Langis, J. (2003). Experimentation with a socio-constructivist process for climate change education. Environmental Education Research,9(4), 429-446. doi: $10.1080 / 1350462032000126096$

Pruneau, D., Liboiron, L., Vrain, E., Gravel, H., Bourque, W., \& Langis, J. (2001). People's ideas about climate change: A source of inspiration for the creation of educational programs. Canadian Journal of Environmental Education, 6, 121-138.

Punter, P., Ochando-Pardo, M., \& García, J. (2011). Spanish secondary students' notions on the causes and consequences of climate change. International Journal of Science Education, 33(3), 447-464. doi: $10.1080 / 09500693.2010 .492253$

Ratinen, I., Viiri, J., \& Lehesvuori, S. (2013). Primary school student teachers' understanding of climate change: Comparing the results given by concept map and communication analysis. Research in Science Education, 43(5), 1801-1823. doi: 10.1080/09500693.2011.587845

Reinfried, S., \& Tempelmann, S. (2014). The impact of secondary school students' preconceptions on the evolution of their mental models of the greenhouse effect and global warming. International Journal of Science Education, 36(2), 304-333. doi: 10.1080/09500693.2013.773598

Rickinson, M. (2001). Learners and learning in environmental education: A critical review of the evidence. Environmental Education Research, 7(3), 207-320. doi: 10.1080/13504620120065230

Roth, C. (1992). Environmental literacy: Its roots, evolution and directions in the 1990s. Columbus, OH: ERIC Clearinghouse for Science, Mathematics, and Environmental Education.

Roychoudhury, A., Shepardson, D. P., \& Hirsch, A. S. (2017). System thinking and teaching in the context of climate system and climate change. In D. P Shepardson, A. Roychoudhury, A. S. Hirsch (Eds.), Teaching and learning about climate change (pp. 29-42). New York: Routledge. 
This is a post-peer-review, pre-copyedit version of an article published inResearch in Science Education. The final authenticated version is available online at: https://doi.org/10.1007/s11165-018-9703-1

Schraw, G., Crippen, K. J., \& Hartley, K. (2006). Promoting self-regulation in science education: Metacognition as part of a broader perspective on learning. Research in Science Education, 36(1-2), 111-139. doi: 10.1007/s11165-005-3917-8

Schwarz, C. V., Reiser, B. J., Davis, E. A., Kenyon, L., Acher, A., Fortus, D., Shwartz, Y., Hug, B., \& Krajcik, J. (2009). Developing a learning progression for scientific modeling: Making scientific modeling accessible and meaningful for learners. Journal of Research in Science Teaching, 46(6), 632-654.

Shepardson, D. P., Niyogi, D., Choi, S., \& Charusombat, U. (2009). Seventh grade students' conceptions of global warming and climate change. Environmental Education Research, 15(5), 549-570. doi: $10.1080 / 13504620903114592$

Shepardson, D. P., Choi, S., Niyogi, D., \& Charusombat, U. (2011a). Seventh grade students' mental models of the greenhouse effect. Environmental Education Research,17(1), 1-17. doi: $10.1080 / 13504620903564549$

Shepardson, D. P., Niyogi, D., Choi, S., \& Charusombat, U. (2011b). Students' conceptions about the greenhouse effect, global warming, and climate change. Climatic Change, 104(3-4), 481-507. doi: 10.1007/s10584-009-9786-9

Shepardson, D. P., Roychoudhury, A., \& Hirsch, A. S. (2017). Using conceptual and physical models to develop students' mental models of the greenhouse effect. In D. P Shepardson, A. Roychoudhury, A. S. Hirsch (Eds.), Teaching and learning about climate change (pp. 85-105). New York: Routledge.

Strickhouser, N., Roychoudhury, A., Hirsch, A. S., \& Mehta, J. V. (2017). Teaching informed by conceptual difficulties with understanding the greenhouse effect. In D. P Shepardson, A. Roychoudhury, A. S. Hirsch (Eds.), Teaching and learning about climate change (pp. 203-214). New York: Routledge.

Taber, F., \& Taylor, N. (2009). Climate of concern - A search for effective strategies for teaching children about global warming. International Journal of Environmental and Science Education, 4(2), 97-116.

Taylor, S. J., \& Bodgan, R. (1998). Introduction to qualitative research methods: A guidebook and resource. New York: John Wiley \& Sons, Inc.

UNESCO (1989). Environmental literacy for all. Connect, 14(2), 1-8.

United Nations (1992). United Nations framework convention on climate change: Text. Geneva: United Nations Environment Programme (UNEP)/ World Meteorological Organization (WMO). 
This is a post-peer-review, pre-copyedit version of an article published inResearch in Science Education. The final authenticated version is available online at: https://doi.org/10.1007/s11165-018-9703-1

Yazdanparast, T., Salehpour, S., Masjedi, M. R., Seyedmehdi, S. M., Boyes, E., Stanisstreet, M., \& Attarchi, M. (2013). Global warming: Knowledge and views of Iranian students. Acta Medica Iranica, 51(3), 178.

Yin, R. K. (2003). Case study research. Desing and methods. California: Sage Publications. 